\title{
Vertical Forces Acting on the Lock-Off Element of the Pallet Brake System
}

\author{
Leopold Hrabovský ${ }^{*}$, Tomáš Mlčák ${ }^{2}$
}

1 VSB Technical University of Ostrava, Faculty of Mechanical Engineering, Institute of Transport, 17. listopadu 2172/15, 70800 Ostrava - Poruba, Czech Republic

2 VSB Technical University of Ostrava, Faculty of Electrical Engineering and Computer Science, Department of Electrical Engineering, 17. listopadu 2172/15, 70800 Ostrava - Poruba, Czech Republic

* Corresponding author's e-mail: leopold.hrabovsky@vsb.cz

\begin{abstract}
The paper presents an experimental device that was created in order to obtain the real values of the forces acting in the vertical direction on the lock-off element, the so-called brake body, the 2nd design option. The lock of this design is used in the automated parking garage, designed by KOMA - Industry, s.r.o, to lock the parked vehicles on pallets in the units of the rack parking system. The forces acting in the vertical direction on the body of the fixation lock when pushing the brake pulley into the circular recess in the brake ramp are theoretically calculated for two design variants of the brake ramp used in practice, i.e. "without" and "with" a rounded (filleted) circular recess segment in the brake ramp. The experimentally determined forces acting in the vertical direction on the brake body were determined for two types of compression coil springs with a rectangular cross section of the spring wire.
\end{abstract}

Keywords: lock, pushing pulley into the recess, coil spring, force effects.

\section{INTRODUCTION}

The forces exerted while pushing the pulley of the brake of the pallet lock-off system (2nd design option; see Figure 1,2, and 4 [4]) into the circular recess of the brake ramp, were experimentally obtained on a device designed for testing parking brakes (see Figure 1), the parts and design of which (1st design option of the brake pulley; see Figure 2), were described in detail in [1].

For the 1st design option of brake (see Figure 2), the limit switch 46 is attached, Figure 5a, model ME-8108 [3], to the pallet brake body 28 by two pairs of screws 47 (M4 $\times 25$ $\mathrm{mm})$ and $48(\mathrm{M} 4 \times 12 \mathrm{~mm})$. The Brake ramp 24 is fastened to the rectangular profile of the frame structure by a screw $50(\mathrm{M} 12 \times 65 \mathrm{~mm})$. Tension bars 49 (diameter $10 \mathrm{~mm}$, length $70 \mathrm{~mm}$ ) of the limit switch 46 are screwed into two holes with M8 thread on the side surface of the brake 24 .
Brake ramp 24 (original design see [2] Figure 2) has been structurally modified for the purpose of measurements, see Figure 3, due to the bending of the threaded rod 11 that connects the charge 34 motion screw 35 with holder 32 brake bodies 28 (see [1] Figure 1). The bending of the threaded rod 11 is caused by the forces generated when rolling the brake pulley over the inclined surface of the brake ramp 24 , i.e. when moving the brake body 28 from vertical profiles 2.1 and 2.2 steel element of a device for testing parking brakes. The brake ramp 24 is supported by a spacer 51 with a thickness of $3 \mathrm{~mm}$, see Figures 2 and 4 , which creates the required design distance between the brake pulley circumference and the rectangular profile 1.2 frame construction.

Limit switch 52, Figure 5b, model ME-8112 [9], see Figure 4, is in the 2nd design option of the brake of the pallet locking system fastened to the brake body 28 by two pairs of screws 47 

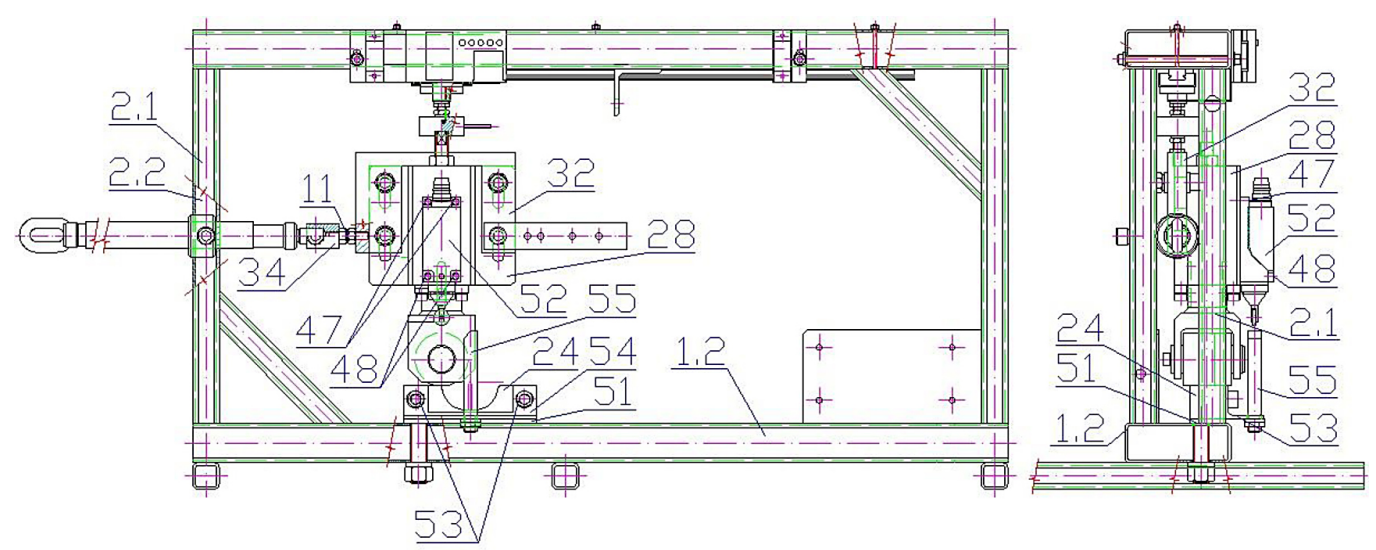

Fig. 1. 2D design of the device for testing parking brakes [1]

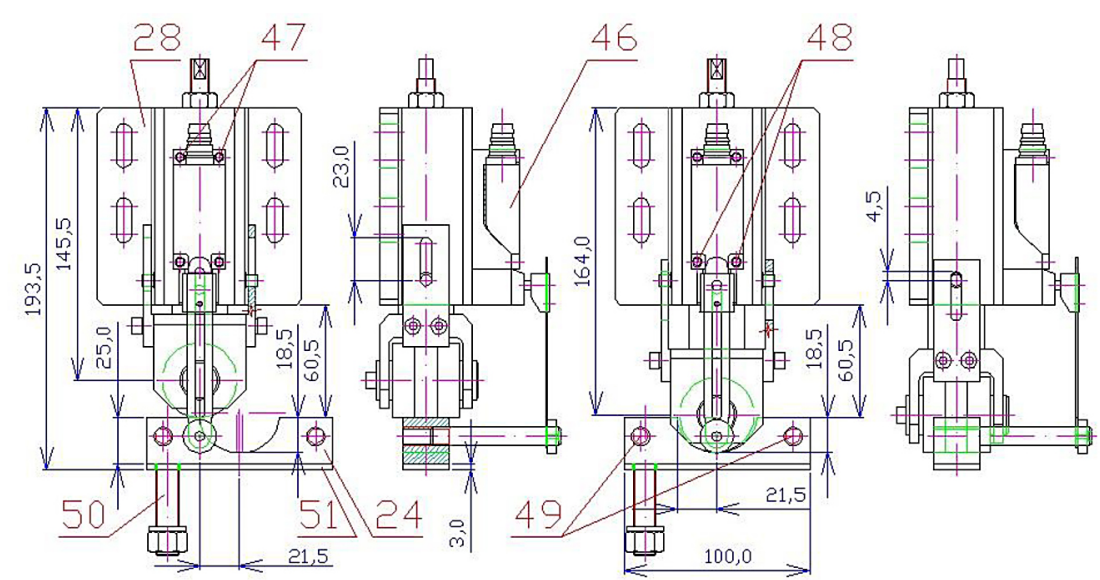

Fig. 2. Pallet parking brake option 1, constructionally modified brake ramp
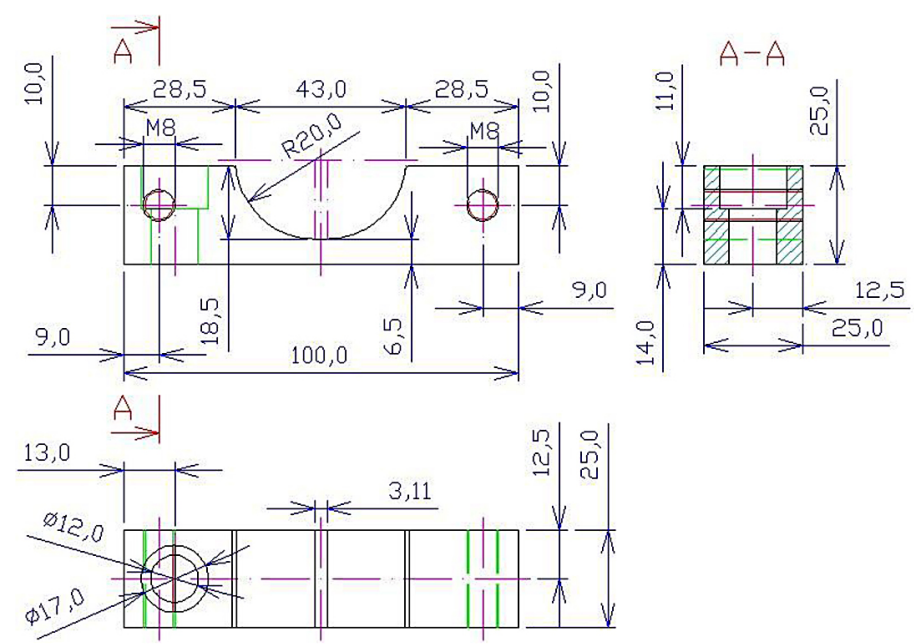

Fig. 3. Designed brake ramp

and 48 . The holder 54 of the tension bars 55 is fastened to the side of the front of the brake 24 with two screws 53. The experimental measurement of forces while pushing the pulley of the 2nd design option (see Figure 4) of the brakes of the pallet lock-off system from the circular recess in the brake ramp was performed with three types of compression cylindrical coil springs V16-102 $[5,8]$, R16-102 [6, 8] (see also Figure 7 [4]) and G16-102 [7, 8].

The upper edges of the circular recess of the brake ramp can be created without a fillet, see Figure 6 or with a fillet (radius $r=1 \mathrm{~mm}$ ), see Figure 7. 

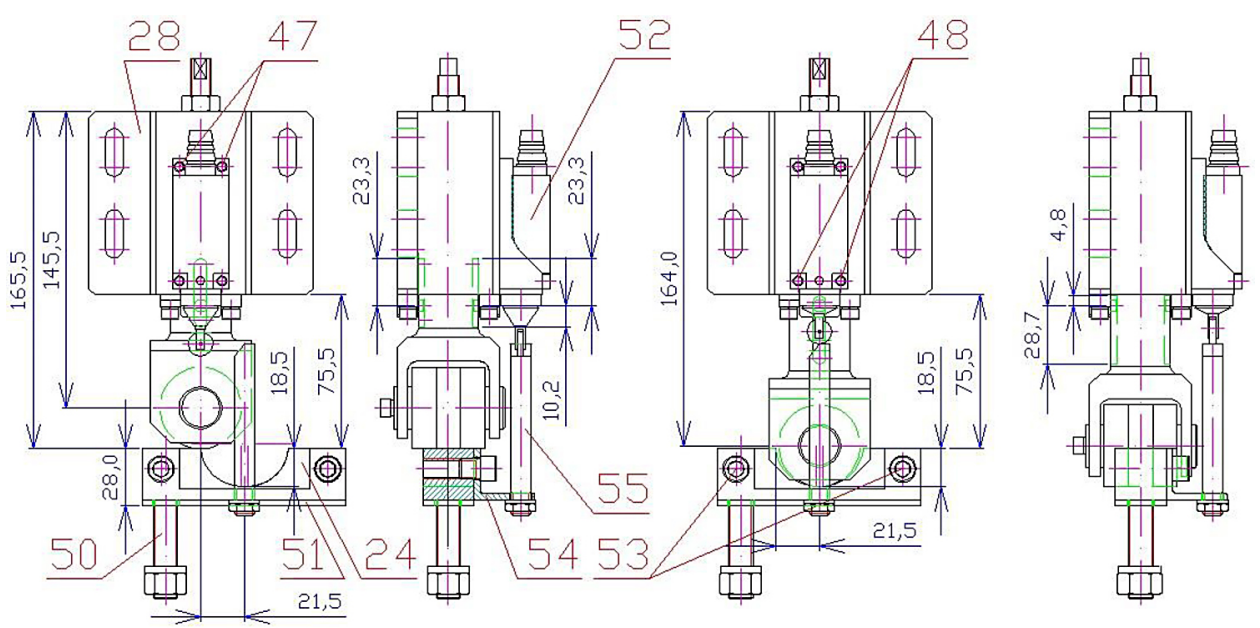

Fig. 4. Pallet parking brake option 2, constructionally modified brake ramp
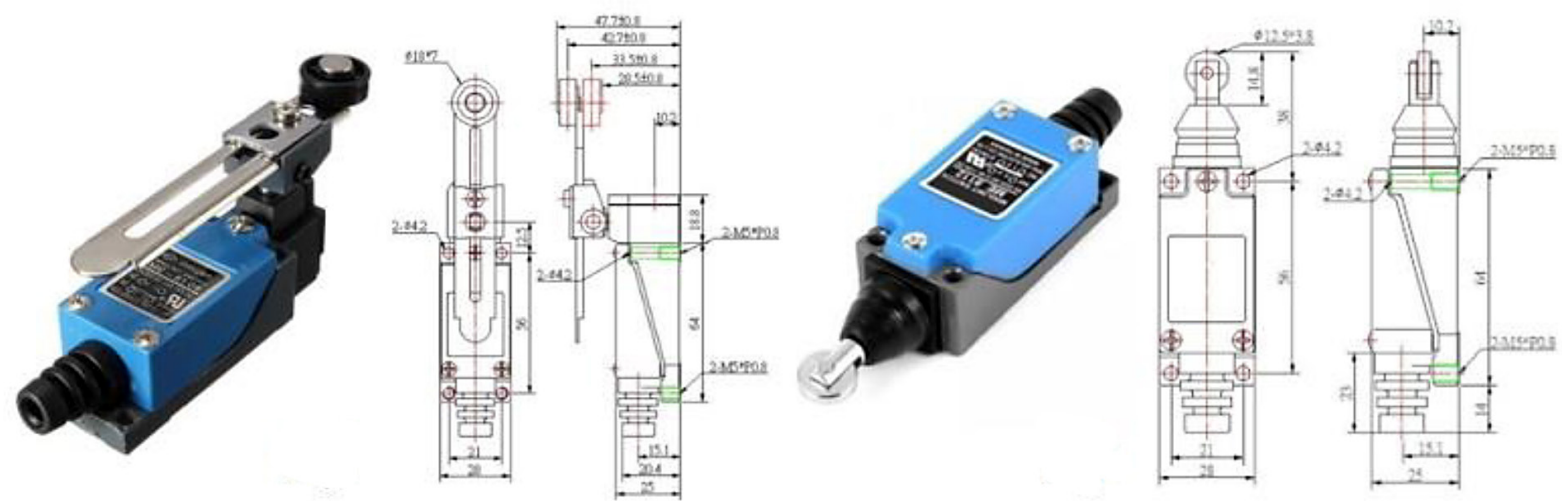

Fig. 5. Limit switch a) ME-8108 [3], b) ME-8112 [9]

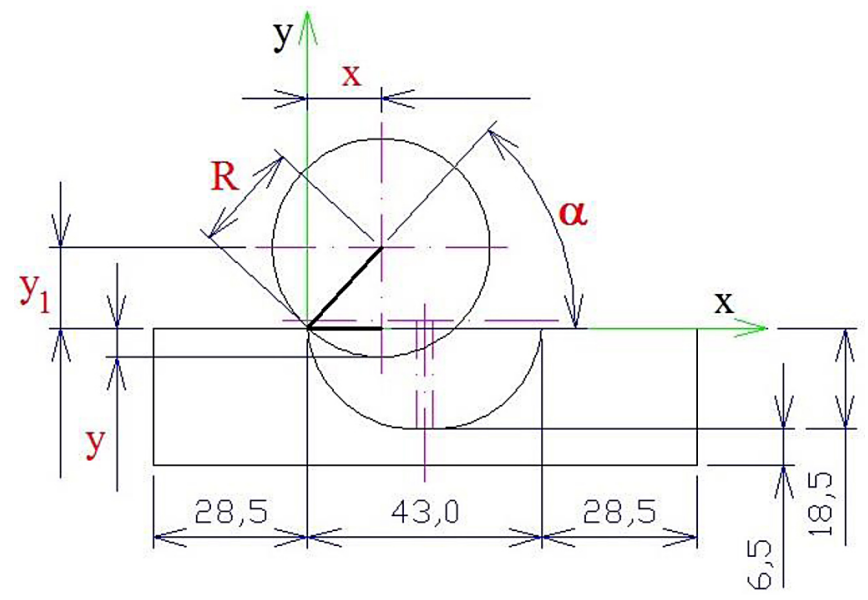

Fig. 6. Brake ramp without filleting of edges of the circular recess in the brake ramp

\section{GENERATED FORCES ON THE BRAKE BODY IN VERTICAL DIRECTION}

The compression forces in the spring are proportional to the vertical distance of the tangent to the lower surface of the outer circumference of the pulley from the upper surface of the profile 1.2, see Figure 1. When the brake pulley is outside the brake ramp, the lower surface of the pulley is located vertically from the upper surface of the profile 1.2 by $\mathrm{h}_{0}=8 \mathrm{~mm}$. If the brake pulley is in contact with the upper surface of the brake, the lower surface of the pulley is located vertically from the upper surface 


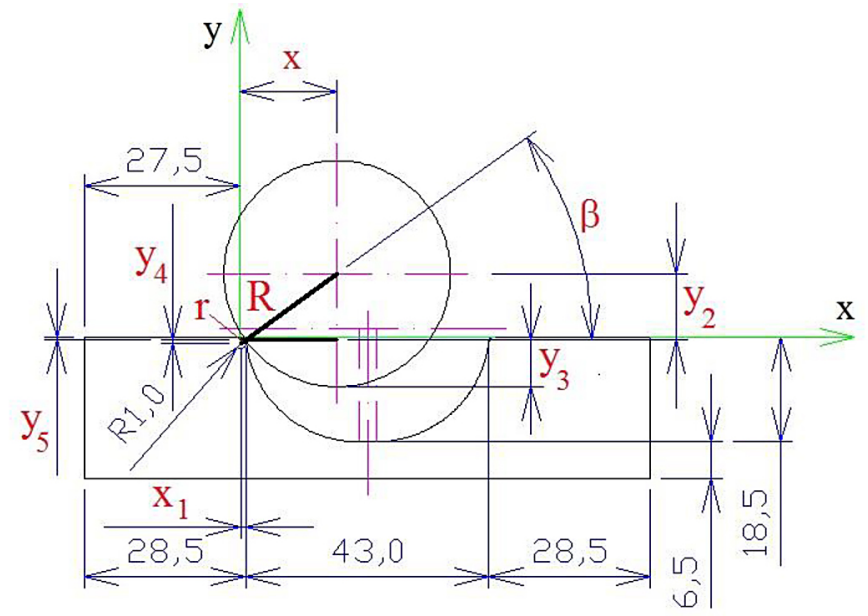

Fig. 7. Brake ramp with a filleted circular recess in the brake ramp

of the profile 1.2 by $\mathrm{h}_{1}=\mathrm{t}_{\mathrm{dp}}+\mathrm{h}_{\mathrm{nb}}-\mathrm{h}_{0}=20 \mathrm{~mm}$ (acc Figure 3, $\mathrm{t}_{\mathrm{dp}}=3 \mathrm{~mm}$ - spacer plate thickness $51, \mathrm{~h}_{\mathrm{nb}}=25 \mathrm{~mm}$ - height of the adjusted brake ramp 24).

Before the experimental measurements were carried out, the brake pulley was brought to its initial position. The default position is the horizontal distance $\mathrm{x}_{\mathrm{v} 1}=28.5 \mathrm{~mm}$ for the filleted brake ramp (see Figure 6), i.e. the vertical axis of the brake pulley extends through the edge of the circular recess of the brake ramp.

The starting position of the filleted brake ramp is the horizontal distance $\mathrm{x}_{\mathrm{v} 2}=27.5 \mathrm{~mm}$ (see Figure 7), i.e. the vertical axis of the brake pulley is away from the vertical axis of the rounded edge of the circular recess by the value $\left(1-\mathrm{x}_{1}=1-0.91=\right) 0.09 \mathrm{~mm}$.

Vertical displacement y $[\mathrm{m}]$, see Figure 6, the tangents to the lower outer peripheral surface of the pulley with respect to the upper surface of the brake ramp can be expressed according to the relationship (3). The relationships (1) to (3) are determined according to Figure 6.

$$
\begin{gathered}
\cos \alpha=\frac{x}{R} \Rightarrow \alpha=\arccos \left(\frac{x}{R}\right)[\operatorname{deg}] \\
\sin \alpha=\frac{y_{1}}{R} \Rightarrow y_{1}=R \cdot \sin \alpha[m] \\
y=R-y_{1}=R \cdot(1-\sin \alpha)[m]
\end{gathered}
$$

The compressive forces exerted by springs (V16-102, R16-102 or G16-102); when pushing the brake pulley in and out of the filleted circular recess of the brake ramp in the pallet lock-off system, are listed in Table 1.
Vertical displacement y [m], see Figure 7, the tangents to the lower outer peripheral surface of the pulley with respect to the upper surface of the brake ramp can be expressed according to the relationship (9). The relationships (4) to (9) are determined according to Figure 7, provided that $\mathrm{x}_{1}=0.91 \mathrm{~mm}$.

$$
\begin{gathered}
\cos \beta=\frac{\mathrm{x}-\mathrm{x}_{1}}{\mathrm{R}+\mathrm{r}} \Rightarrow \beta=\arccos \left(\frac{\mathrm{x}-\mathrm{x}_{1}}{\mathrm{R}+\mathrm{r}}\right)[\mathrm{deg}] \\
\sin \beta=\frac{\mathrm{y}_{2}}{\mathrm{R}} \Rightarrow \mathrm{y}_{2}=\mathrm{R} \cdot \sin \beta[\mathrm{m}] \\
\mathrm{y}_{3}=\mathrm{R}-\mathrm{y}_{2}=\mathrm{R} \cdot(1-\sin \beta)[\mathrm{m}] \\
\sin \beta=\frac{\mathrm{y}_{4}}{\mathrm{r}} \Rightarrow \mathrm{y}_{4}=\mathrm{r} \cdot \sin \beta[\mathrm{m}] \\
\mathrm{y}_{5}=\mathrm{r}-\mathrm{y}_{4}=\mathrm{r} \cdot(1-\sin \beta)[\mathrm{m}] \\
\mathrm{y}=\mathrm{y}_{3}+\mathrm{y}_{5}=\mathrm{R} \cdot(1-\sin \beta)+\mathrm{r} . \\
\cdot(1-\sin \beta)=(1-\sin \beta) .(\mathrm{R}+\mathrm{r})[\mathrm{m}]
\end{gathered}
$$

The compressive forces exerted by springs (V16-102, R16-102 or G16-102); while the brake pulley is moving through the filleted circular recess of the brake ramp of the pallet lock-off system; are listed in Table 2.

The theoretical determined compressive forces in the springs when pushing the brake pulley out of the circular recess in the brake ramp, when the edges of the recess are and are not filleted (see Table 2) is shown in Figure 8.

In this paper [1] the design of the device for testing parking brakes which utilized the brake of 
Table 1. Compressive forces as the brake pulley passes along the unfilleted brake ramp

\begin{tabular}{|c|c|c|c|c|c|c|c|c|c|c|c|}
\hline$x[\mathrm{~mm}]$ & 0 & 1 & 2 & 3 & 4 & 5 & 6 & 7 & 8 & 9 & 10 \\
\hline $\mathrm{x}_{\mathrm{sk}}=\mathrm{x}_{\mathrm{v} 1}+\mathrm{x}[\mathrm{mm}]$ & 28.5 & 29.5 & 30.5 & 31.5 & 32.5 & 33.5 & 34.5 & 35.5 & 36.5 & 37.5 & 38.5 \\
\hline $\mathrm{y}[\mathrm{mm}$ & 0 & 0.03 & 0.10 & 0.23 & 0.40 & 0.64 & 0.92 & 1.27 & 1.67 & 2.14 & 2.68 \\
\hline $\mathrm{y}_{\mathrm{sk}}[\mathrm{mm}]$ & 20 & 19.97 & 19.90 & 19.77 & 19.60 & 19.36 & 19.08 & 18.73 & 18.33 & 17.86 & 17.32 \\
\hline $\mathrm{F}_{\mathrm{V} 16}[\mathrm{~N}]$ & 156.0 & 155.8 & 155.2 & 154.2 & 152.9 & 151.0 & 148.8 & 146.1 & 143.0 & 139.3 & 135.1 \\
\hline $\mathrm{F}_{\mathrm{R} 16}[\mathrm{~N}]$ & 386.0 & 385.4 & 384.1 & 381.6 & 378.3 & 373.6 & 368.2 & 361.5 & 353.8 & 344.7 & 334.3 \\
\hline $\mathrm{F}_{\mathrm{G} 16}[\mathrm{~N}]$ & 512.0 & 511.2 & 509.4 & 506.1 & 501.8 & 495.6 & 488.4 & 479.5 & 469.2 & 457.2 & 443.4 \\
\hline $\mathrm{x}[\mathrm{mm}]$ & 11 & 12 & 13 & 14 & 15 & 16 & 17 & 18 & 19 & 20 & 21 \\
\hline$x_{s k}=x_{v 1}+x[m m]$ & 39.5 & 40.5 & 41.5 & 42.5 & 43.5 & 44.5 & 45.5 & 46.5 & 47.5 & 48.5 & 49.5 \\
\hline $\mathrm{y}[\mathrm{mm}$ & 3.30 & 4.00 & 4.80 & 5.72 & 6.77 & 8.00 & 9.46 & 11.28 & 13.76 & 18.50 & 18.50 \\
\hline $\mathrm{y}_{\mathrm{sk}}[\mathrm{mm}]$ & 16.70 & 16.00 & 15.20 & 14.28 & 13.23 & 12.00 & 10.54 & 8.72 & 6.24 & 1.50 & 1.50 \\
\hline $\mathrm{F}_{\mathrm{V} 16}[\mathrm{~N}]$ & 130.3 & 124.8 & 118.6 & 111.4 & 103.2 & 93.6 & 82.2 & 68.0 & 48.7 & 11.7 & 11.7 \\
\hline $\mathrm{F}_{\mathrm{R} 16}[\mathrm{~N}]$ & 322.3 & 308.8 & 293.4 & 275.6 & 255.3 & 231.6 & 203.4 & 168.3 & 120.4 & 29.0 & 29.0 \\
\hline $\mathrm{F}_{\mathrm{G} 16}[\mathrm{~N}]$ & 427.5 & 409.6 & 389.1 & 365.6 & 338.7 & 307.2 & 269.8 & 223.2 & 159.7 & 38.4 & 38.4 \\
\hline $\mathrm{x}[\mathrm{mm}]$ & 22 & 23 & 24 & 25 & 26 & 27 & 28 & 29 & 30 & 31 & 32 \\
\hline$x_{s k}=x_{v 1}+x[m m]$ & 50.5 & 51.5 & 52.5 & 53.5 & 54.5 & 55.5 & 56.5 & 57.5 & 58.5 & 59.5 & 60.5 \\
\hline $\mathrm{y}[\mathrm{mm}$ & 18.50 & 18.50 & 13.76 & 11.28 & 9.46 & 8.00 & 6.77 & 5.72 & 4.80 & 4.00 & 3.30 \\
\hline $\mathrm{y}_{\mathrm{sk}}[\mathrm{mm}]$ & 1.50 & 1.50 & 6.24 & 8.72 & 10.54 & 12.00 & 13.23 & 14.28 & 15.20 & 16.00 & 16.70 \\
\hline $\mathrm{F}_{\mathrm{V} 16}[\mathrm{~N}]$ & 11.7 & 11.7 & 48.7 & 68.0 & 82.2 & 93.6 & 103.2 & 111.4 & 118.6 & 124.8 & 130.3 \\
\hline $\mathrm{F}_{\mathrm{R} 16}[\mathrm{~N}]$ & 29.0 & 29.0 & 120.4 & 168.3 & 203.4 & 231.6 & 255.3 & 275.6 & 293.4 & 308.8 & 322.3 \\
\hline $\mathrm{F}_{\mathrm{G} 16}[\mathrm{~N}]$ & 38.4 & 38.4 & 159.7 & 223.2 & 269.8 & 307.2 & 338.7 & 365.6 & 389.1 & 409.6 & 427.5 \\
\hline $\mathrm{x}[\mathrm{mm}]$ & 33 & 34 & 35 & 36 & 37 & 38 & 39 & 40 & 41 & 42 & 43 \\
\hline$x_{\mathrm{sk}}=\mathrm{x}_{\mathrm{v} 1}+\mathrm{x}[\mathrm{mm}]$ & 61.5 & 62.5 & 63.5 & 64.5 & 65.5 & 66.5 & 67.5 & 68.5 & 69.5 & 70.5 & 71.5 \\
\hline $\mathrm{y}[\mathrm{mm}$ & 2.68 & 2.14 & 1.67 & 1.27 & 0.92 & 0.64 & 0.40 & 0.23 & 0.10 & 0.03 & 0 \\
\hline $\mathrm{y}_{\mathrm{sk}}[\mathrm{mm}]$ & 17.32 & 17.86 & 18.33 & 18.73 & 19.08 & 19.36 & 19.60 & 19.77 & 19.90 & 19.97 & 20.00 \\
\hline $\mathrm{F}_{\mathrm{V} 16}[\mathrm{~N}]$ & 135.1 & 139.3 & 143.0 & 146.1 & 148.8 & 151.0 & 152.9 & 154.2 & 155.2 & 155.8 & 156.0 \\
\hline $\mathrm{F}_{\mathrm{R} 16}[\mathrm{~N}]$ & 334.3 & 344.7 & 353.8 & 361.5 & 368.2 & 373.6 & 378.3 & 381.6 & 384.1 & 385.4 & 386.0 \\
\hline $\mathrm{F}_{\mathrm{G} 16}[\mathrm{~N}]$ & 443.4 & 457.2 & 469.2 & 479.5 & 488.4 & 495.6 & 501.8 & 506.1 & 509.4 & 511.2 & 512.0 \\
\hline
\end{tabular}

the pallet of the 1st design is described in detail, (for details see [2] Figures 1 and 2). In [1] the tables show the experimentally obtained horizontal $\mathrm{F}_{\mathrm{xij}}[\mathrm{N}]$ and vertical $\mathrm{F}_{\mathrm{yij}}[\mathrm{N}]$ forces measured by means of MCF30 - 500 N force transducers depending on the horizontal displacement of the pallet brake body of the 1st option, i.e. when the brake pulley rolled on the upper surface of the brake ramp.

Forces acting on the 2nd design option of the pallet lock-off system brake

In a real parking garage, the rotating part of the brake does not move right up to the holder of the brake (height $h_{d}=8 \mathrm{~mm}$.).

This way of attaching the brake body is not suitable, as in the moment when the brake pulley is located in the circular recess of the brake ramp, the pallet is allowed to move horizontally in the range $h_{h}=5.5 \mathrm{~mm}$. At the same time, at the actual construction height of the brake $h_{n b}=36 \mathrm{~mm}$, when the brake pulley is pushed out of the circular recess in the brake ramp, spring y is compressed $d_{p}=h_{n b}-h_{t o}-h_{d}=13 \mathrm{~mm}$. The parking garage is equipped with compression cylindrical coil springs type R16-102 $\mathrm{k}_{\mathrm{p}}=19.3 \mathrm{~N} / \mathrm{mm}$.

$$
\mathrm{y}_{\mathrm{k}}=\mathrm{h}_{\mathrm{d}}+\mathrm{h}_{\mathrm{k}}+\mathrm{R}-\mathrm{h}_{\mathrm{nb}}[\mathrm{m}]
$$

$\sin \alpha=\frac{\mathrm{y}_{\mathrm{k}}}{\mathrm{R}} \Rightarrow \alpha=\arcsin \frac{\mathrm{y}_{\mathrm{k}}}{\mathrm{R}}[\mathrm{deg}]$

$\cos \alpha=\frac{x_{k}}{R} \Rightarrow x_{k}=R \cdot \cos \alpha[m]$

$\sum \mathrm{M}_{0}=0: \mathrm{F}_{\mathrm{p}} \cdot \mathrm{x}_{\mathrm{k}}-\mathrm{F}_{\mathrm{x}} \cdot \mathrm{y}_{\mathrm{k}}=0[\mathrm{~N} \cdot \mathrm{m}] \Rightarrow$

$\Rightarrow \mathrm{F}_{\mathrm{x}}=\mathrm{F}_{\mathrm{p}} \cdot \frac{\mathrm{x}_{\mathrm{k}}}{\mathrm{y}_{\mathrm{k}}}[\mathrm{N}]$

According to $[1,2]$ and relationship (13), the maximum value of instantaneous force $\mathrm{F}$ acting in a horizontal plane $F_{x}[N]$ can be calculated, which gives the initial displacement of the brake pulley from the circular recess of the brake ramp.

Table 3 presents the theoretically calculated values of the compressive forces exerted by the 
Table 2. Compressive forces as the pulley passes through the filleted recess of the brake ramp

\begin{tabular}{|c|c|c|c|c|c|c|c|c|c|c|c|}
\hline$x[\mathrm{~mm}]$ & 0 & 1 & 2 & 3 & 4 & 5 & 6 & 7 & 8 & 9 & 10 \\
\hline $\mathrm{x}_{\mathrm{sk}}=\mathrm{x}_{\mathrm{v} 2}+\mathrm{x}[\mathrm{mm}]$ & 27.5 & 28.5 & 29.5 & 30.5 & 31.5 & 32.5 & 33.5 & 34.5 & 35.5 & 36.5 & 37.5 \\
\hline $\mathrm{y}[\mathrm{mm}$ & 0 & 0.02 & 0.09 & 0.20 & 0.37 & 0.58 & 0.85 & 1.17 & 1.55 & 1.98 & 2.48 \\
\hline $\mathrm{y}_{\mathrm{sk}}[\mathrm{mm}]$ & 20 & 19.98 & 19.91 & 19.80 & 19.63 & 19.42 & 19.15 & 18.83 & 18.45 & 18.02 & 17.52 \\
\hline $\mathrm{F}_{\mathrm{V} 16}[\mathrm{~N}]$ & 156.0 & 155.8 & 155.3 & 154.4 & 153.1 & 151.5 & 149.4 & 146.9 & 143.9 & 140.6 & 136.7 \\
\hline $\mathrm{F}_{\mathrm{R} 16}[\mathrm{~N}]$ & 386.0 & 385.6 & 384.3 & 382.1 & 378.9 & 374.8 & 369.6 & 363.4 & 356.1 & 347.8 & 338.1 \\
\hline $\mathrm{F}_{\mathrm{G} 16}[\mathrm{~N}]$ & 512.0 & 511.5 & 509.7 & 506.9 & 502.5 & 497.2 & 490.2 & 482.0 & 472.3 & 461.3 & 448.5 \\
\hline$x[\mathrm{~mm}]$ & 11 & 12 & 13 & 14 & 15 & 16 & 17 & 18 & 19 & 20 & 21 \\
\hline$x_{\mathrm{sk}}=\mathrm{x}_{\mathrm{v} 2}+\mathrm{x}[\mathrm{mm}]$ & 38.5 & 39.5 & 40.5 & 41.5 & 42.5 & 43.5 & 44.5 & 45.5 & 46.5 & 47.5 & 48.5 \\
\hline $\mathrm{y}[\mathrm{mm}$ & 3.05 & 3.70 & 4.43 & 5.26 & 6.21 & 7.29 & 8.54 & 10.03 & 11.86 & 14.31 & 18.50 \\
\hline $\mathrm{y}_{\mathrm{sk}}[\mathrm{mm}]$ & 16.95 & 16.30 & 15.57 & 14.74 & 13.79 & 12.71 & 11.46 & 9.97 & 8.14 & 5.69 & 1.50 \\
\hline $\mathrm{F}_{\mathrm{V} 16}[\mathrm{~N}]$ & 132.2 & 127.1 & 121.4 & 115.0 & 107.6 & 99.1 & 89.4 & 77.8 & 63.5 & 44.4 & 11.7 \\
\hline $\mathrm{F}_{\mathrm{R} 16}[\mathrm{~N}]$ & 327.1 & 314.6 & 300.5 & 284.5 & 266.1 & 245.3 & 221.2 & 192.4 & 157.1 & 109.8 & 29.0 \\
\hline $\mathrm{F}_{\mathrm{G} 16}[\mathrm{~N}]$ & 433.9 & 417.3 & 398.6 & 377.3 & 353.0 & 325.4 & 293.4 & 255.2 & 208.4 & 145.7 & 38.4 \\
\hline $\mathrm{x}[\mathrm{mm}]$ & 22 & 23 & 24 & 25 & 26 & 27 & 28 & 29 & 30 & 31 & 32 \\
\hline $\mathrm{x}_{\mathrm{sk}}=\mathrm{x}_{\mathrm{v} 2}+\mathrm{x}[\mathrm{mm}]$ & 49.5 & 50.5 & 51.5 & 52.5 & 53.5 & 54.5 & 55.5 & 56.5 & 57.5 & 58.5 & 59.5 \\
\hline $\mathrm{y}[\mathrm{mm}$ & 18.50 & 18.50 & 18.50 & 14.31 & 11.86 & 10.03 & 8.54 & 7.29 & 6.21 & 5.26 & 4.43 \\
\hline $\mathrm{y}_{\mathrm{sk}}[\mathrm{mm}]$ & 1.50 & 1.50 & 1.50 & 5.69 & 8.14 & 9.97 & 11.46 & 12.71 & 13.79 & 14.74 & 15.57 \\
\hline $\mathrm{F}_{\mathrm{v} 16}[\mathrm{~N}]$ & 11.7 & 11.7 & 11.7 & 44.4 & 63.5 & 77.8 & 89.4 & 99.1 & 107.6 & 115.0 & 121.4 \\
\hline $\mathrm{F}_{\mathrm{R} 16}[\mathrm{~N}]$ & 29.0 & 29.0 & 29.0 & 109.8 & 157.1 & 192.4 & 221.2 & 245.3 & 266.1 & 284.5 & 300.5 \\
\hline $\mathrm{F}_{\mathrm{G} 16}[\mathrm{~N}]$ & 38.4 & 38.4 & 38.4 & 145.7 & 208.4 & 255.2 & 293.4 & 325.4 & 353.0 & 377.3 & 398.6 \\
\hline$x[\mathrm{~mm}]$ & 33 & 34 & 35 & 36 & 37 & 38 & 39 & 40 & 41 & 42 & 43 \\
\hline $\mathrm{x}_{\mathrm{sk}}=\mathrm{x}_{\mathrm{v} 2}+\mathrm{x}[\mathrm{mm}]$ & 60.5 & 61.5 & 62.5 & 63.5 & 64.5 & 65.5 & 66.5 & 67.5 & 68.5 & 69.5 & 70.5 \\
\hline $\mathrm{y}[\mathrm{mm}$ & 3.70 & 3.05 & 2.48 & 1.98 & 1.55 & 1.17 & 0.85 & 0.58 & 0.37 & 0.20 & 0.09 \\
\hline $\mathrm{y}_{\mathrm{sk}}[\mathrm{mm}]$ & 16.30 & 16.95 & 17.52 & 18.02 & 18.45 & 18.83 & 19.15 & 19.42 & 19.63 & 19.80 & 19.91 \\
\hline $\mathrm{F}_{\mathrm{V} 16}[\mathrm{~N}]$ & 127.1 & 132.2 & 136.7 & 140.6 & 143.9 & 146.9 & 149.4 & 151.5 & 153.1 & 154.4 & 155.3 \\
\hline $\mathrm{F}_{\mathrm{R} 16}[\mathrm{~N}]$ & 314.6 & 327.1 & 338.1 & 347.8 & 356.1 & 363.4 & 369.6 & 374.8 & 378.9 & 382.1 & 384.3 \\
\hline $\mathrm{F}_{\mathrm{G} 16}[\mathrm{~N}]$ & 417.3 & 433.9 & 448.5 & 461.3 & 472.3 & 482.0 & 490.2 & 497.2 & 502.5 & 506.9 & 509.7 \\
\hline$x[\mathrm{~mm}]$ & 44 & 45 & & & & & & & & & \\
\hline$\left.x_{s k}=x_{v 2}+x[m m]\right]$ & 71.5 & 72.5 & & & & & & & & & \\
\hline $\mathrm{y}[\mathrm{mm}$ & 0.02 & 0 & & & & & & & & & \\
\hline $\mathrm{y}_{\mathrm{sk}}[\mathrm{mm}]$ & 19.98 & 20.00 & & & & & & & & & \\
\hline $\mathrm{F}_{\mathrm{V} 16}[\mathrm{~N}]$ & 155.8 & 156.0 & & & & & & & & & \\
\hline $\mathrm{F}_{\mathrm{R} 16}[\mathrm{~N}]$ & 385.6 & 386.0 & & & & & & & & & \\
\hline $\mathrm{F}_{\mathrm{G} 16}[\mathrm{~N}]$ & 511.5 & 512.0 & & & & & & & & & \\
\hline
\end{tabular}

V16-102, R16-102 and G16-102 springs when pushing the brake pulley into the filleted circular recess of the brake ramp of the pallet lock-off system, when the tangent from the horizontal plane to the outer surface of the pulley measures $\mathrm{h}_{\mathrm{H}}=8 \mathrm{~mm}$ to the bottom surface of the structurally modified brake ramp. The testing equipment (see Figure 10) is provided with a structurally modified brake ramp with $h_{n}=25 \mathrm{~mm}$ (see Figure 3 ) and the maximum depth of the circular recess in the brake ramp $\mathrm{y}_{\mathrm{p}}=18.5 \mathrm{~mm}$.

$$
\mathrm{y}_{\mathrm{sk}}=\mathrm{y}_{\mathrm{p}}-\mathrm{y}_{\mathrm{H}}-\mathrm{y}[\mathrm{m}]
$$

where:

$$
\mathrm{y}_{\mathrm{H}}=\mathrm{h}_{\mathrm{H}}+\mathrm{y}_{\mathrm{p}}-\mathrm{h}_{\mathrm{n}}=1.5 \mathrm{~mm}
$$

Table 3 shows the actual spring compression $\mathrm{y}_{\mathrm{sk}}[\mathrm{mm}]$ expressed according to the relationship (14).

In this paper, [1] (see Table 4) provides the procedure for the experimental measurements that were performed to obtain the resistance value $\mathrm{F}_{\mathrm{cs}}[\mathrm{N}](=20.52 \mathrm{~N})$ to prevent the roller part of the pulley holder from sliding into the pulley body when the compression coil spring is not in the pallet brake body. 


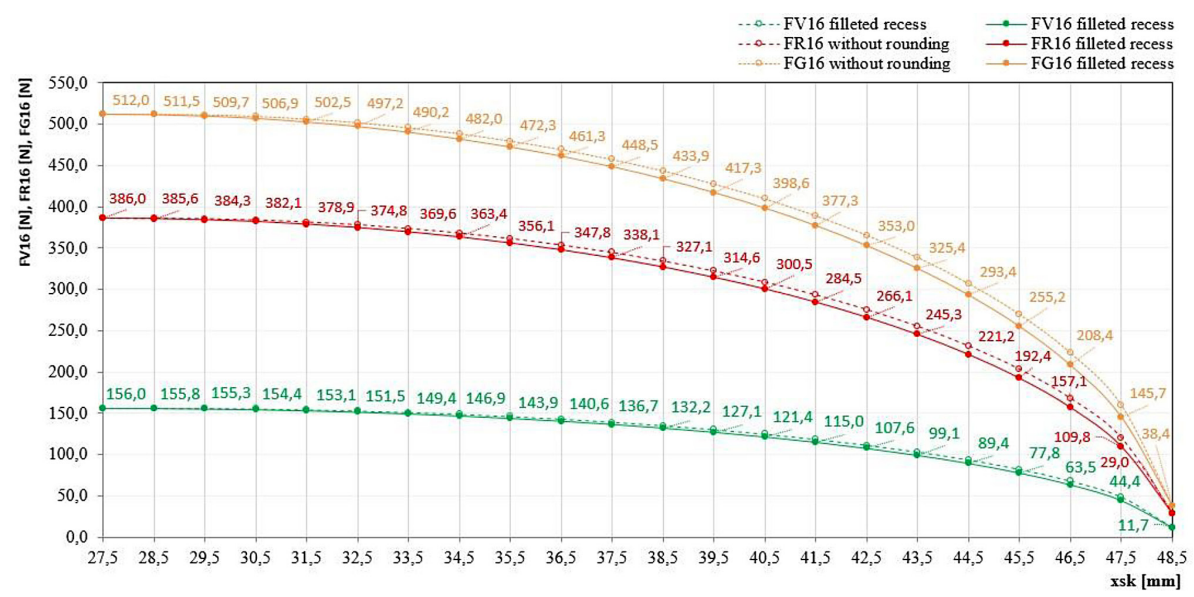

Fig. 8. Theoretically determined compressive forces in the springs when pushing the brake pulley into the circular recess of the brake ramp

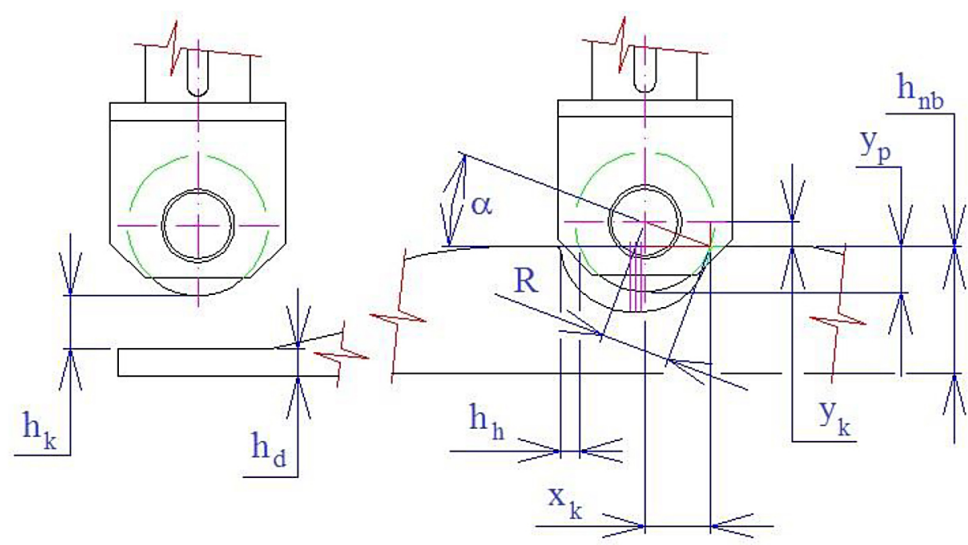

Fig. 9. Dimensional parameters when pushing the pallet brake pulley out of the circular recess in the brake ramp

Table 4 gives the values of the theoretically calculated actual compressive forces in springs $\mathrm{Fm}_{\mathrm{V} 16}-\mathrm{F}_{\mathrm{cs}}[\mathrm{N}], \mathrm{Fm}_{\mathrm{R} 16}-\mathrm{F}_{\mathrm{cs}}[\mathrm{N}]$ and $\mathrm{Fm}_{\mathrm{G} 16}-\mathrm{F}_{\mathrm{cs}}[\mathrm{N}]$.

\section{EXPERIMENTALLY DETERMINED FORCES OF THE 2ND DESIGN BRAKE OPTION}

The values of the compressive forces exerted by the V16-102 springs on the experimental device (see Figure 12) when pushing the brake pulley of the pallet lock-off system into the filleted circular recess of the brake ramp (see Table 5 to Table 6) and R16-102 (see Table 8 to Table 10).

A graphical representation of the compressive forces obtained by measurement (see Table 5 to Table 6), in the V16-102 spring as the brake pulley of the pallet lock-off system is gradually pushed into the filleted circular recess of the brake ramp is shown in Figure 11.
In Figure 11, the green curve shows (according to Table 7) the measured values of the applied forces in the vertical direction on the body of the 2nd brake design option and the red curve gives the values of the theoretically calculated compression forces in the spring $\mathrm{Fm}_{\mathrm{v} 16}-\mathrm{F}_{\mathrm{cs}}[\mathrm{N}]$ (according to Table 4).

The graphic representation of compressive forces obtained by the measurement (see Table 8 to Table 10) in the R16-102 spring as the brake pulley of the pallet arresting system is pressed into the filleted circular recess of the brake ramp is shown in Figure 11.

In Figure 11, the green curve shows (according to Table 10) the measured values of the forces applied in the vertical direction on the body of the 2nd brake design option and the red curve gives the values of the theoretically calculated compression forces in the spring $\mathrm{Fm}_{\mathrm{V} 16}-\mathrm{F}_{\mathrm{cs}}[\mathrm{N}](\mathrm{ac}-$ cording to Table 4). 
Table 3. Compressive forces in the springs when pushing the pulley into the recess of the filleted brake ramp

\begin{tabular}{|c|c|c|c|c|c|c|c|c|c|c|}
\hline$x[\mathrm{~mm}]$ & 0 & 1 & 2 & 3 & 4 & 5 & 6 & 7 & 8 & 9 \\
\hline $\mathrm{x}_{\mathrm{sk}}=\mathrm{x}_{\mathrm{v} 2}+\mathrm{x}[\mathrm{mm}]$ & 27.5 & 28.5 & 29.5 & 30.5 & 31.5 & 32.5 & 33.5 & 34.5 & 35.5 & 36.5 \\
\hline $\mathrm{y}[\mathrm{mm}$ & 0 & 0.02 & 0.09 & 0.20 & 0.37 & 0.58 & 0.85 & 1.17 & 1.55 & 1.98 \\
\hline $\mathrm{y}_{\mathrm{sk}}[\mathrm{mm}]$ & 17 & 16.98 & 16.91 & 16.8 & 16.63 & 16.42 & 16.19 & 15.83 & 15.45 & 15.02 \\
\hline $\mathrm{Fm}_{\mathrm{V} 16}[\mathrm{~N}]$ & 132.6 & 132.4 & 131.9 & 131.0 & 129.7 & 128.1 & 126.0 & 123.5 & 120.5 & 117.1 \\
\hline $\mathrm{Fm}_{\mathrm{R} 16}[\mathrm{~N}]$ & 328.1 & 327.7 & 326.4 & 324.2 & 321.0 & 316.9 & 311.7 & 305.5 & 298.2 & 289.8 \\
\hline $\mathrm{Fm}_{\mathrm{G} 16}[\mathrm{~N}]$ & 435.2 & 434.7 & 433.0 & 430.0 & 425.8 & 420.3 & 413.5 & 405.3 & 395.6 & 384.4 \\
\hline$x[\mathrm{~mm}]$ & 10 & 11 & 12 & 13 & 14 & 15 & 16 & 17 & 18 & 19 \\
\hline$x_{s k}=x_{v 2}+x[m m]$ & 37.5 & 38.5 & 39.5 & 40.5 & 41.5 & 42.5 & 43.5 & 44.5 & 45.5 & 46.5 \\
\hline $\mathrm{y}[\mathrm{mm}$ & 2.49 & 3.06 & 3.70 & 4.44 & 5.27 & 6.21 & 7.29 & 8.55 & 10.03 & 11.87 \\
\hline $\mathrm{y}_{\mathrm{sk}}[\mathrm{mm}]$ & 14.51 & 13.94 & 13.30 & 12.56 & 11.73 & 10.79 & 9.71 & 8.45 & 6.97 & 5.13 \\
\hline $\mathrm{Fm}_{\mathrm{v} 16}[\mathrm{~N}]$ & 113.2 & 108.8 & 103.7 & 98.0 & 91.5 & 84.1 & 75.7 & 65.9 & 54.3 & 40.0 \\
\hline $\mathrm{Fm}_{\mathrm{R} 16}[\mathrm{~N}]$ & 280.1 & 269.1 & 256.6 & 242.5 & 226.4 & 208.2 & 187.3 & 163.1 & 134.4 & 99.1 \\
\hline $\mathrm{Fm}_{\mathrm{G} 16}[\mathrm{~N}]$ & 371.6 & 357.0 & 340.4 & 321.6 & 300.4 & 276.2 & 248.5 & 216.4 & 178.3 & 131.4 \\
\hline$x[\mathrm{~mm}]$ & 20 & & $21 \div 24$ & & & & & & & \\
\hline$x_{s k}=x_{v 2}+x[m m]$ & 47.5 & 48.21 & $48.5 \div 51.5$ & & & & & & & \\
\hline $\mathrm{y}[\mathrm{mm}$ & 14.32 & 17 & 17 & & & & & & & \\
\hline $\mathrm{y}_{\mathrm{sk}}[\mathrm{mm}]$ & 2.68 & 0 & 0 & & & & & & & \\
\hline $\mathrm{Fm}_{\mathrm{V} 16}[\mathrm{~N}]$ & 20.9 & 0 & 0 & & & & & & & \\
\hline $\mathrm{Fm}_{\mathrm{R} 16}[\mathrm{~N}]$ & 51.7 & 0 & 0 & & & & & & & \\
\hline $\mathrm{Fm}_{\mathrm{G} 16}[\mathrm{~N}]$ & 68.5 & 0 & 0 & & & & & & & \\
\hline
\end{tabular}

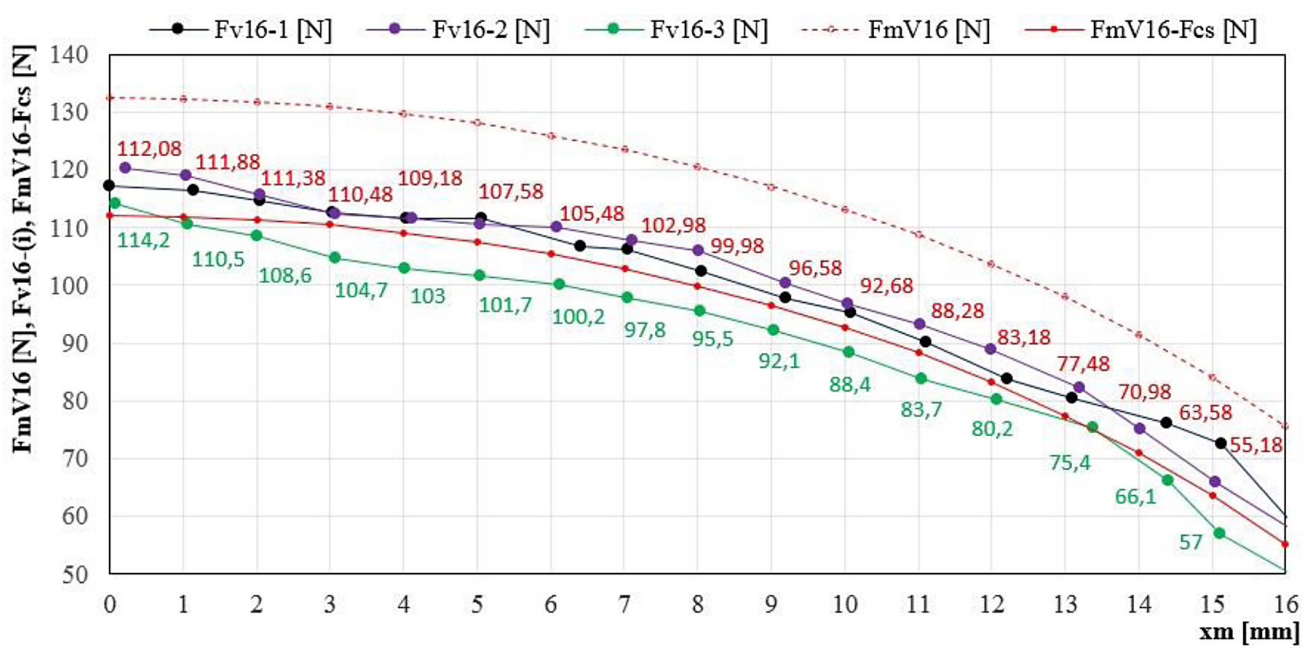

Fig. 10. Compressive forces in the V16-102 spring when pushing the brake pulley into the circular recess in the brake ramp obtained by measurement

Table 4. Values of the theoretically calculated compression forces in the spring

\begin{tabular}{|l|c|c|c|c|c|c|c|c|c|}
\hline $\mathrm{x}[\mathrm{mm}]$ & 0 & 1 & 2 & 3 & 4 & 5 & 6 & 7 & 8 \\
\hline $\mathrm{Fm}_{\mathrm{V} 16}-\mathrm{F}_{\mathrm{cS}}[\mathrm{N}]$ & 112.08 & 111.88 & 111.38 & 110.48 & 109.18 & 107.58 & 105.48 & 102.98 & 99.98 \\
\hline $\mathrm{Fm}_{\mathrm{R} 16}-\mathrm{F}_{\mathrm{cS}}[\mathrm{N}]$ & 307.58 & 307.18 & 305.88 & 303.68 & 300.48 & 296.38 & 291.18 & 284.98 & 277.68 \\
\hline $\mathrm{Fm}_{\mathrm{G} 16}-\mathrm{F}_{\mathrm{cs}}[\mathrm{N}]$ & 414.68 & 414.18 & 412.48 & 409.48 & 405.28 & 399.78 & 392.98 & 384.78 & 375.08 \\
\hline $\mathrm{X}[\mathrm{mm}]$ & 9 & 10 & 11 & 12 & 13 & 14 & 15 & 16 & \\
\hline $\mathrm{Fm}_{\mathrm{V} 16}-\mathrm{F}_{\mathrm{cS}}[\mathrm{N}]$ & 96.58 & 92.68 & 88.28 & 83.18 & 77.48 & 70.98 & 63.58 & 55.18 & \\
\hline $\mathrm{Fm}_{\mathrm{R} 16}-\mathrm{F}_{\mathrm{cS}}[\mathrm{N}]$ & 269.28 & 259.58 & 248.58 & 236.08 & 221.98 & 205.88 & 187.68 & 166.78 & \\
\hline $\mathrm{Fm}_{\mathrm{G} 16}-\mathrm{F}_{\mathrm{cs}}[\mathrm{N}]$ & 363.88 & 351.08 & 336.48 & 319.88 & 301.08 & 279.88 & 255.68 & 227.98 & \\
\hline
\end{tabular}


Table 5.

\begin{tabular}{|l|c|c|c|c|c|c|c|c|c|}
\hline $\mathrm{X}_{\mathrm{m}}[\mathrm{mm}]$ & 0 & 1.14 & 2.05 & 3.03 & 4.03 & 5.07 & 6.40 & 7.04 & 8.05 \\
\hline $\mathrm{Fv}_{16-1}[\mathrm{~N}]$ & 117.3 & 116.5 & 114.6 & 111.6 & 111.5 & 111.5 & 106.7 & 106.2 & 102.4 \\
\hline $\mathrm{X}_{\mathrm{m}}[\mathrm{mm}]$ & 9.19 & 10.09 & 11.10 & 12.22 & 13.09 & 14.39 & 15.13 & 16.09 & \\
\hline $\mathrm{Fv}_{16-1}[\mathrm{~N}]$ & 97.9 & 95.3 & 90.1 & 83.8 & 80.4 & 76.2 & 72.5 & 58.8 & \\
\hline
\end{tabular}

Table 6.

\begin{tabular}{|l|c|c|c|c|c|c|c|c|c|}
\hline $\mathrm{x}_{\mathrm{m}}[\mathrm{mm}]$ & 0.22 & 1.05 & 2.05 & 3.08 & 4.12 & 5.04 & 6.08 & 7.11 & 8.01 \\
\hline $\mathrm{Fv}_{16-2}[\mathrm{~N}]$ & 120.2 & 118.9 & 115.7 & 112.3 & 111.6 & 110.7 & 110.1 & 107.9 & 105.9 \\
\hline $\mathrm{X}_{\mathrm{m}}[\mathrm{mm}]$ & 9.20 & 10.05 & 11.02 & 12.00 & 13.20 & 14.03 & 15.05 & 16.06 & \\
\hline $\mathrm{Fv}_{16-2}[\mathrm{~N}]$ & 100.3 & 96.9 & 93.2 & 88.8 & 82.3 & 75.1 & 65.9 & 57.9 & \\
\hline
\end{tabular}

Table 7.

\begin{tabular}{|l|c|c|c|c|c|c|c|c|c|}
\hline $\mathrm{X}_{\mathrm{m}}[\mathrm{mm}]$ & 0.08 & 1.07 & 2.01 & 3.08 & 4.01 & 5.04 & 6.13 & 7.05 & 8.04 \\
\hline $\mathrm{Fv}_{16-3}[\mathrm{~N}]$ & 122.9 & 119.2 & 117.3 & 113.4 & 111.7 & 110.4 & 108.9 & 106.5 & 104.2 \\
\hline $\mathrm{X}_{\mathrm{m}}[\mathrm{mm}]$ & 9.04 & 10.07 & 11.04 & 12.07 & 13.37 & 14.40 & 15.10 & 16.03 & \\
\hline $\mathrm{Fv}_{16-3}[\mathrm{~N}]$ & 100.8 & 97.1 & 92.4 & 88.9 & 84.1 & 74.8 & 65.7 & 59.1 & \\
\hline
\end{tabular}

Table 8.

\begin{tabular}{|l|c|c|c|c|c|c|c|c|c|}
\hline $\mathrm{x}_{\mathrm{m}}[\mathrm{mm}]$ & 0.14 & 1.04 & 2.05 & 3.15 & 4.05 & 5.04 & 6.08 & 7.05 & 8.02 \\
\hline $\mathrm{Fr}_{16-1}[\mathrm{~N}]$ & 334.8 & 339.8 & 343.3 & 345.5 & 344.2 & 339.6 & 327 & 320.1 & 305.5 \\
\hline $\mathrm{x}_{\mathrm{m}}[\mathrm{mm}]$ & 9.05 & 10.12 & 11.11 & 12.07 & 13.1 & 14.04 & 15.21 & 16.10 & \\
\hline $\mathrm{Fr}_{16-1}[\mathrm{~N}]$ & 295.4 & 279.6 & 262.2 & 252.7 & 239.6 & 219.5 & 198.3 & 176.4 & \\
\hline
\end{tabular}

Table 9.

\begin{tabular}{|l|c|c|c|c|c|c|c|c|c|}
\hline $\mathrm{x}_{\mathrm{m}}[\mathrm{mm}]$ & 0.01 & 1.06 & 2.06 & 3.04 & 4.01 & 5.01 & 6.05 & 7.05 & 8.02 \\
\hline $\mathrm{Fr}_{16-2}[\mathrm{~N}]$ & 345.1 & 346.3 & 346.8 & 342.3 & 336.3 & 327.2 & 314.1 & 305.9 & 290.1 \\
\hline $\mathrm{x}_{\mathrm{m}}[\mathrm{mm}]$ & 9.03 & 10.01 & 11.17 & 12.07 & 13.20 & 14.02 & 15.03 & 16.16 & \\
\hline $\mathrm{Fr}_{16-2}[\mathrm{~N}]$ & 278.1 & 269.5 & 256.7 & 241.2 & 227.8 & 209.6 & 186.6 & 164.8 & \\
\hline
\end{tabular}

Table 10.

\begin{tabular}{|l|c|c|c|c|c|c|c|c|c|}
\hline $\mathrm{x}_{\mathrm{m}}[\mathrm{mm}]$ & 0.01 & 1.06 & 2.11 & 3.03 & 4.21 & 5.07 & 6.03 & 7.05 & 8.03 \\
\hline $\mathrm{Fr}_{16-3}[\mathrm{~N}]$ & 346.9 & 346.4 & 341.6 & 339.8 & 327.9 & 316.9 & 307.8 & 296.7 & 279.6 \\
\hline $\mathrm{X}_{\mathrm{m}}[\mathrm{mm}]$ & 9.02 & 10.02 & 11.15 & 12.2 & 13.14 & 14.26 & 15.36 & 16.30 & \\
\hline $\mathrm{Fr}_{16-3}[\mathrm{~N}]$ & 264.8 & 254.2 & 241.6 & 228.2 & 211.8 & 187.6 & 166.2 & 148.7 & \\
\hline
\end{tabular}

The graphs, created by means of the DEWESoft X2 SP5 software installed on a PC, show the acting force in the direction of vertical axis depending on the horizontal displacement $\mathrm{L}[\mathrm{mm}]$ of the pallet brake. The projection information was stored in the form of data files on the PC disk, see Figure 12.

Due to the limited scope of the paper, only the values of the experimentally obtained forces acting in the vertical direction on the body of the 2nd design option of the brake (into which springs V16-102 and R16-102 were inserted) while pushing the brake pulley into the filleted circular recess are given above (see Figure 7). Figure 13 presents the device implemented for testing the parking lock-off brake of the 2 nd design option. 


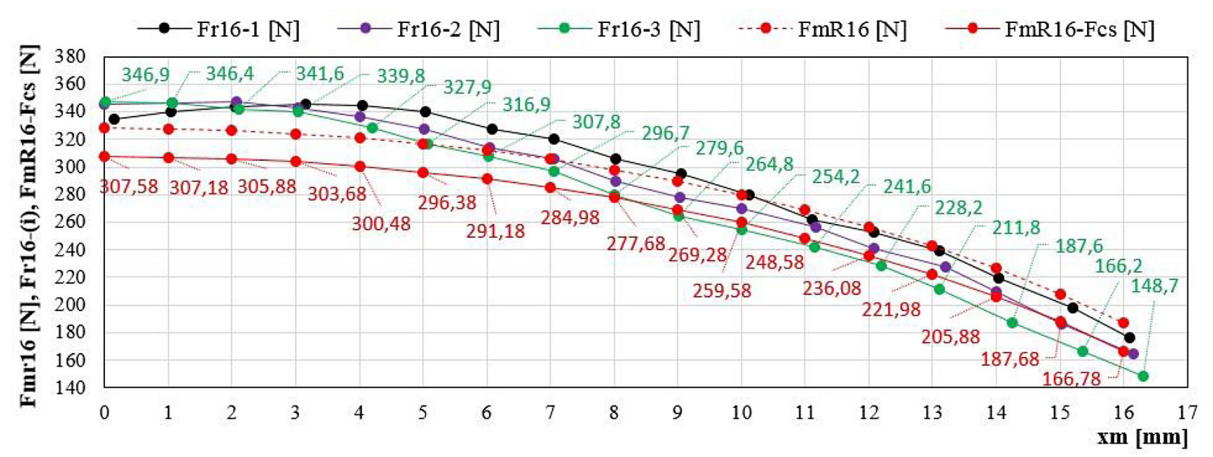

Fig. 11. Compressive forces in the R16-102 spring when pushing the brake pulley into the circular recess in the brake ramp obtained by measurement

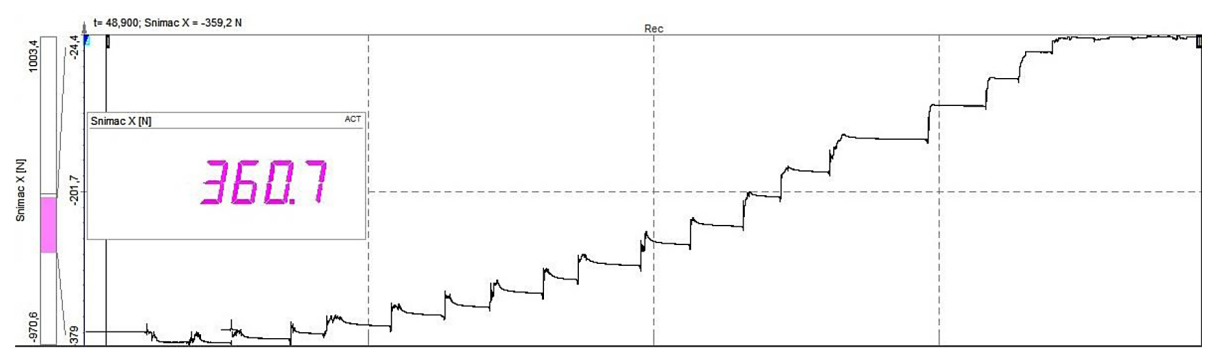

Fig. 12. Recording force in DEWESoft X2 SP5

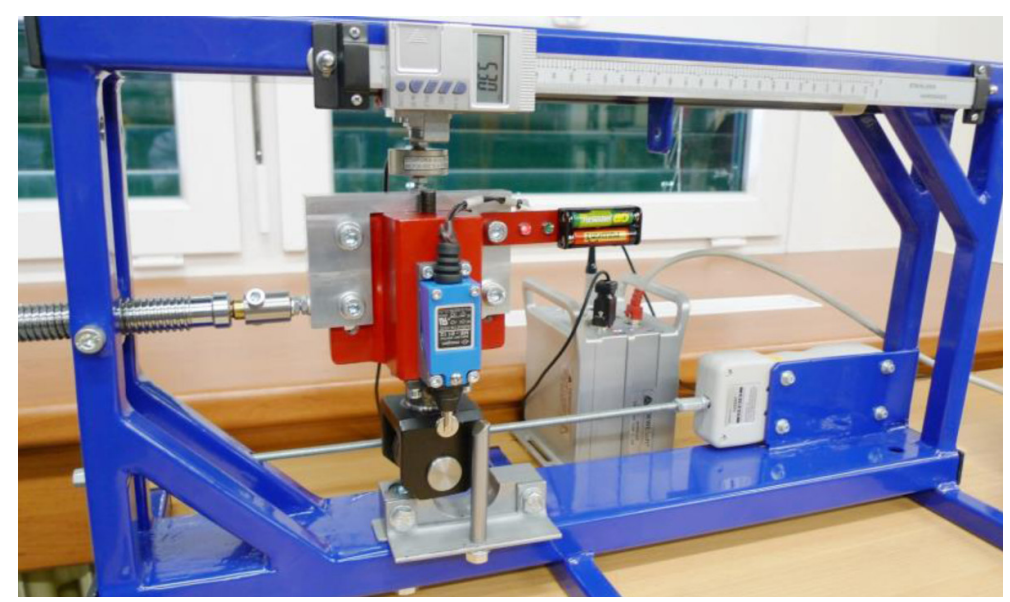

Fig. 13. A device for testing parking brakes using the 2 nd design option of the parking lock-off brake

\section{CONCLUSION}

Both options of the installed lock-off brakes, so-called pallet parking brakes, in the automated parking garage, see Figure 2 and Figure 4, exhibit a substantial design deficiency, which substantially affects the amount of the vertical compression force to be exerted by the compression coil spring when inserting into / withdrawing from the cylindrical segment of the pulley holder of the brake body. The design deficiency is that in the recess of the brake body there is: (i) overpressure when pushing the cylindrical part of the brake carrier into the opening of the brake body (when rolling the pulley over the slope part of the brake), (ii) underpressure when forcing the partially compressed compression spring out of the cylindrical recess part of the brake holder from the brake body (during insertion of the brake pulley into the circular recess in the brake ramp).

The overpressure / underpressure is generated by the fact that the contact surface between the outer cylindrical surface of the brake holder and the inner surface of the spacer ring ( pressed 
into the recess in the brake body) is lubricated with grease in order to prevent the shear friction, which prevents the air from coming in and out of the brake body. It is recommended that a hole be created in the body of both brake options to expel the air creating the pressure / underpressure from the area of the hole in the brake body.

The pallets are pushed into the rack cells by two chain conveyor carriers. Each of the carriers is attached to two roller chains which are connected in a closed loop. The axial distance and pitch of the sprockets allow the outer surfaces of the carriers to pass over the exactly given radius when the carriers pass from the upper to the lower branch of the chain conveyor. The rotating part (pulley) of the lock-off brake in the parking garage does not reach the brake holder of the brake ramp but is at $15 \mathrm{~mm}$ distance from the brake ramp holder. This distance allows the pallet on which the parked vehicle is placed to move horizontally by $5.5 \mathrm{~mm}$ in the direction of the pallet insertion into the rack cell.

The function of the carriers is to capture the pallet and push / pull it out of the rack cell. The pallet capturing is done by the carriers which must be inserted into the inner parts of the locks (C-shaped) located on the underside of the pallet. The carrier attached to the transition links of the chain, from the lower to the upper branch of the chain conveyor, may not be successful if the pallet is in an inappropriate position, the carriers may not slide into the locks (C-shaped) of the pallet. One of the unsuitable positions of the pallet preventing its attachment, is its high insertion position (allowing the pallet to shift by $5.5 \mathrm{~mm}$ ) in the rack cell.

In order to limit this undesired state when the carriers are not able to lock-off the pallet, sensors are mounted on the brake bodies of both structure options indicating, whether the pallet is in the desired position.

\section{Acknowledgements}

This work has been supported by The Ministry of Education, Youth and Sports of the Czech Republic from the Specific Research Project SP2019/101 and a Contract for work No. S40/19-342-01.

\section{REFERENCES}

1. Hrabovský, L., Žáček, V.: Forces in the lock-off device during the rolling of the brake pulley roller over the brake ramp in the built automatic parking house. IOP Conference Series: Materials Science and Engineering, 2020 (in Press).

2. Hrabovský L., Mlčák T. and Kotajný G.: Forces Generated in the Parking Brake of the Pallet Locking System. Advances in Science and Technology Research Journal, 13(4), 2019, 31-37.

3. https://www.gme.cz/prumyslovy-koncovy-spinacme-8108-nastavitelne-rameno-s-valeckem

4. Hrabovský L., Dluhoš D.: Calibration of Transducers and of a Coil Compression Spring Constant on the Testing Equipment Simulating the Process of a Pallet Positioning in a Rack Cell. Open Engineering. Issue: Actual trends in logistics and industrial engineering, 2019. (in Press).

5. ht t p s: // w w w. e i c h lercompany.cz/ pruziny/ vinute-pruziny/pruzina-v-1/ vinuta-pruzina-s551331282

6. ht t p s : / / w w w . e i c h le r c o m pany.cz/ pruziny/ vinute-pruziny/pruzina-r-1/ vinuta-pruzina-s551371782

7. ht t p s: // w w w. ei chlercompany.cz/ pruziny/vinute-pruziny/pruzina-g-1/ vinuta-pruzina-s551379146

8. https://www.eichlercompany.cz/ download/katalogy/SPECIAL-SPRINGS/Katalog-Springs-Vinutepruziny-2018.pdf 